\title{
AS COTAS RACIAIS NO PAÍS DO FUTEBOL, ONDE MUITOS PARDOS SÃO "GATOS"
}

Adilson Pereira dos Santos (UFOP) ${ }^{1}$

\section{RESUMO}

$\mathrm{O}$ ensaio analisa as fraudes nas cotas raciais, aprovadas pelas Leis $\mathrm{n}^{\circ} 12.711 / 2012$ e $\mathrm{n}^{\mathrm{o}} 12.990 / 2014$, à luz da naturalização do levar vantagem a qualquer custo, prática que, no futebol, ficou conhecida como a Lei de Gérson. Trata-se de um recorte de pesquisa que investigou a implementação da Lei de Cotas em três universidades mineiras. Concluiu que a autodeclaração como mecanismo exclusivo para comprovação da condição de beneficiário das cotas raciais, não tem se revelado eficaz aos objetivos dessas políticas públicas. Pessoas não negras vêm se autodeclarando como tal e ocupando essas vagas. Essa situação impulsionou à adoção da heteroidentificação, visando o seu real público alvo.

Palavras-chave: Políticas de ação afirmativa. Lei de Cotas. Fraudes. Comissões de heteroidentificação. Lei de Gérson.

\section{RACIAL QUOTAS IN THE SOCCER COUNTRY: WHERE MANY BROWNS ARE "CATS"}

\begin{abstract}
The article analyzes the fraud in racial quotas, approved by Laws No. 12,711 / 2012 and No. 12,990 / 2014 , in light of the naturalization of taking advantage at any cost, a practice that in football, became known as the Gérson Law. This is a section of research that investigated the implementation of the Quota Law in three universities in Minas Gerais. He concluded that self-declaration as an exclusive mechanism for proving the condition of beneficiary of racial quotas, has not been effective for the objectives of these public policies. Non-black people have been declaring themselves as such and occupying these vacancies. This situation led to the adoption of heteroidentification, targeting its real target audience.
\end{abstract}

Keywords: Affirmative action policies, Quota Law, Fraud, Hetero-identification Commissions, Gérson Law.

\section{CUOTAS RACIALES EN EL PAÍS DEL FÚTBOL: DONDE MUCHOS MARRONES SON "GATOS"}

\begin{abstract}
RESUMEN
El artículo analiza el fraude en las cuotas raciales, aprobado por las Leyes $\mathrm{N}^{\circ} 12.711 / 2012$ y N ${ }^{\circ}$ 12.990 / 2014, a la luz de la naturalización del aprovechamiento a toda costa, práctica que en el fútbol pasó a conocerse como Ley Gérson. Esta es una sección de investigación que investigó la implementación de la Ley de Cuotas en tres universidades de Minas Gerais. Concluyó que la autodeclaración como mecanismo exclusivo para acreditar la condición de beneficiario de cuotas raciales, no ha sido eficaz para los objetivos de estas políticas públicas. La gente no negra se ha estado declarando como tal y ocupando estas vacantes. Esta situación llevó a la adopción de la heteroidentificación, dirigida a su público objetivo real.
\end{abstract}

Palabras clave: Políticas de acción afirmativa, Ley de cuotas, Fraude, Comisiones de heteroidentificación, Ley Gérson.

1 Contato: adilson.santos@ufop.edu.br. 


\section{NOTAS INTRODUTÓRIAS - FRAUDES NAS COTAS RACIAIS, A LIÇÃO QUE VEM DO FUTEBOL}

No Brasil, o futebol mais do que um esporte de competição é um fenômeno social que confere identidade à Nação. Nosso país é conhecido mundo afora pelo que representa no contexto das quatro linhas. Recorremos à popularidade do esporte para retratar um fenômeno social recente, marcado pelas denúncias de fraudes nas cotas raciais destinadas a pretos e pardos (negros), pelas leis $\mathrm{n}^{\mathrm{o}} 12.711 / 2012$ e $\mathrm{n}^{\mathrm{o}}$ 12.990/2014. A primeira lei, trata-se da reserva de vagas no ensino superior e técnico de nível médio (BRASIL, 2012), e a segunda, em concursos públicos (BRASIL, 2014) 2 .

A título de ilustração elegemos a figura do gato, para retratar as fraudes, tendo como referência o uso desse termo no futebol. No contexto do futebol, nos anos de 1970, passou a ser difundida a ideia de que esperta seria aquela pessoa capaz de levar vantagens em tudo. A prática ganhou a mídia e se popularizou como Lei de Gérson, que traduzia esse comportamento social. Gérson, ou Canhotinha de Ouro, foi um craque de futebol que jogou em vários clubes, com destaque para o Fluminense/RJ e a seleção brasileira. Ficou bastante conhecido fora dos gramados, pois, converteu-se em garoto propaganda de uma marca de cigarros e como comentarista de futebol na TV e no rádio ${ }^{3}$. Na chamada publicitária do cigarro Vila Rica, Gérson asseverava: "gosto de levar vantagem em tudo. Certo? Leve vantagem você também!” (NUNES, 1976).

A terminologia Lei de Gérson foi cunhada pelo jornalista Maurício Dias e divulgada pelo psicanalista Jurandir Freire Costa “para designar a ideologia do 'levar vantagem em tudo', pela qual se pauta uma certa (anti) ética da vida pública no país” (KEHL, 1992). Essa ideologia faz crer que, no futebol, crimes como o do "gato" compensam

[a] violência em campo, quando usada para "impor respeito" sobre o adversário, é muitas vezes estimulada por treinadores. Xingamentos que em qualquer situação cotidiana levariam ao chilindró, os autores são gritados com orgulho por torcidas nas arquibancadas. Mas nenhum, absolutamente nenhum crime compensa mais do que o "gato", ou a adulteração da idade para buscar mais oportunidades na base (VENÂNCIO, 2017).

No que tange à propalada Lei de Gérson, frequentemente deparamos com as denúncias de "gatos" no futebol brasileiro. Tratam-se de pessoas querendo tirar vantagens e favorecer os seus clubes, alterando a idade do jogador para competir numa categoria de idade que não é a

\footnotetext{
${ }^{2}$ Há vagas reservadas para negros e negras também nos concursos para provimento de cargos da Administração Pública Federal, conforme Decreto n ${ }^{\circ}$ 9.427, na pós-graduação, por incentivo da Portaria CAPES n ${ }^{\circ}$ 13/2016, dentre outras iniciativas de ação afirmativa.

${ }^{3}$ Ainda hoje, Gérson é comentarista da Rádio Tupi, no Rio de Janeiro.

REVISTA ENSAIOS E PESQUISA EM EDUCAÇÃO E CULTURA - 2020. 2 / vol . 5 - n.9 
sua. Venâncio (2017) elencou alguns casos envolvendo os atletas: Brendon ou Helton, do Paulista Futebol Clube, Sandro Hiroshi, Anaílson, Leandro Lima, Carlos Alberto (exFigueirense), Cláudio (ex-Palmeiras), Michel Schmöller, Emerson Sheik e muitos outros. Todos continuaram jogando futebol. Para o autor, no futebol, o crime de falsidade ideológica, previsto no Código Penal Brasileiro, acaba amenizado. Nenhum dos mencionados cumpriu a pena de reclusão de um a cinco anos, prevista no art. 299 (BRASIL, 1940). As penas acabaram sendo de multa e/ou prestação de serviços comunitários. Além disso, sofreram suspensão por um curto período, depois retomaram as atividades, como se nada houvesse acontecido. O "gato" também é utilizado para caracterizar um outro tipo de malfeito, que é a ligação clandestina de energia elétrica.

Esse estímulo ao crime e incentivo à impunidade se enquadra no cenário que estamos vivenciando com a implementação das Leis de Cotas.

O pressuposto é o de que, um número significativo de autodeclarados pardos seriam "gatos". Não teriam as características exigidas para ocupar tais vagas, porém, no entanto concorrem a elas. Nesse sentido, a autodeclaração do candidato ou da candidata deve ser confrontada com a heteroidentificação, realizada por comissões designadas para esse fim. Assim, o objetivo deste ensaio é refletir sobre em que medida a ideologia do levar vantagem a qualquer preço (Lei de Gérson) estaria influenciando a autodeclaração prestada por determinados candidatos e determinadas candidatas às vagas reservadas para negros e negras.

\section{INICIANDO A REFLEXÃO - AS COTAS RACIAIS NA REALIDADE BRASILEIRA}

As cotas raciais representam uma das possibilidades de efetivação das políticas de ação afirmativa destinadas aos grupos étnico-raciais em situações de desigualdades. No caso em tela, analisaremos a sua aplicação no acesso aos ensinos superior e técnico de nível médio, e nos concursos da esfera federal. Conceitualmente, as políticas de ação afirmativa são medidas adotadas por órgãos públicos ou por entidades da iniciativa privada com o objetivo de mitigar prejuízos históricos ou presentes, decorrentes de processos de discriminação racial, social, econômica, de gênero, por deficiência, geracional, por procedência escolar, local de moradia, entre outros. Segundo Madruga (2005, p. 72), “o principal objetivo desse tipo de política é garantir a consecução do princípio de igualdade de oportunidades entre determinados grupos ou indivíduos excluídos socialmente".

As iniciativas originárias tiveram lugar na Índia e nos Estados Unidos e focalizavam grupos raciais, os/as dalits (intocáveis) no primeiro caso, e os negros e as negras nos EUA. Sua aplicação é mais conhecida no acesso ao ensino superior, no emprego público e nos meios de comunicação. 
No Brasil, quem pautou as ações afirmativas na agenda política foi o Movimento Social Negro (MSN), que compreende "as mais diversas formas de organização e articulação das negras e dos negros politicamente posicionados na luta contra o racismo..." (GOMES 2017, p. 23). As condições em que se deu a inserção dos africanos e das africanas na sociedade brasileira produziram sequelas que, passados mais de 130 anos da falsa abolição (1888) ainda hoje são observadas. Com destaque à prática do racismo, que é estrutural em nossa sociedade e está arraigado nas instituições, produzindo efeitos e consequências perversas. É nesse contexto que são reivindicadas as ações afirmativas que, para Petruccelli (2007), representariam resposta

a forma como são percebidos segmentos da população nacional e, portanto, como são classificados em categorias, sejam estas acadêmicas ou populares, condiciona a vida de cada indivíduo em sociedade, resultando em privações diversas para aqueles aos que se atribuem características estigmatizadas (p. 113).

Foi, portanto, no limiar do século XXI, que o pleito histórico do MSN começou a ser concretizado. Uma das expressões mais contundentes foi a aprovação da Lei $\mathrm{n}^{\mathrm{o}}$ 12.711, sancionada no dia 29 de agosto de 2012, que estabeleceu a obrigatoriedade da reserva de vagas para candidatos e candidatas egressos de escolas públicas nas universidades e nas instituições federais de ensino técnico de nível médio (BRASIL, 2012). A Lei consolida as reservas de vagas em âmbito nacional, representando uma conquista para os grupos beneficiados. Mas, ações afirmativas análogas se faziam presentes no Brasil, desde 2002, tendo como instituições pioneiras a Universidade do Estado do Rio de Janeiro (Uerj), a Universidade do Estado Norte Fluminense Darcy Ribeiro (Uenf), a Universidade do Estado do Mato Grosso do Sul (UEMS), a Universidade Estadual da Bahia (Uneb) e a Universidade de Brasília (UnB) (SANTOS, 2012).

De acordo com a Lei, $50 \%$ das vagas em todos os cursos e turnos são reservadas para candidatos e candidatas egressos de escolas públicas, de baixa renda, negros (pretos e pardos) e indígenas. Mediante alteração introduzida pela Lei $n^{0}$ 13.409/2016, a Lei também reserva vagas para pessoas com deficiência (BRASIL, 2016b). Os percentuais de vagas reservadas para negros (pretos e pardos) e indígenas e para pessoas com deficiência leva em consideração a proporção desses grupos na unidade da federação na qual está instalada a instituição, com base no Censo da Fundação Instituto Brasileiro de Geografia e Estatística (IBGE). Outra importante política de ação afirmativa na mesma perspectiva foi formalizada por meio da Lei $\mathrm{n}^{\circ} 12.990$, de 9 de junho de 2014, que reserva 20\% de vagas para negros e negras, nos concursos para provimento de cargos efetivos e empregos, na administração pública federal, autarquias, fundações, empresas e sociedades de economia mista controladas pela União. 


\section{REAIS BENEFICIÁRIOS DAS COTAS RACIAIS E A CLASSIFICAÇÃO ÉTNICO- RACIAL NO BRASIL}

As duas leis em exame definiram a autodeclaração étnico-racial como procedimento a ser utilizado para conferir aos candidatos e às candidatas o direito ao benefício das cotas raciais. $\mathrm{O}$ art. $3^{\circ}$ da Lei $\mathrm{n}^{\mathrm{o}} 12.711 / 2012$ prescreve que em cada instituição de ensino, as vagas serão "preenchidas, por curso e turno, por autodeclarados pretos, pardos e indígenas..." (BRASIL, 2012). A Lei $n^{\circ} 12.990 / 2014$, por sua vez, estabelece que "poderão concorrer às vagas reservadas a candidatos negros aqueles que se autodeclararem pretos ou pardos no ato da inscrição no concurso público" (BRASIL, 2014). Essa última prevê a adoção de mecanismo complementar à autodeclaração, na hipótese de constatação de declaração falsa, com a possibilidade de eliminação do candidato. Essa possibilidade se materializou em procedimento obrigatório, por meio da Orientação Normativa $n^{\circ} 3$, de $1^{\circ}$ de agosto de 2016, emanada pelo Ministério do Planejamento, Orçamento e Gestão (MPOG) ${ }^{4}$ (BRASIL, 2016c), reforçada pela Recomendação n ${ }^{o}$ 41, do Conselho Nacional do Ministério Público (CNMP), datada de 6 de agosto de 2016 (BRASIL, 2016d).

Como se vê, para o acesso ao ensino superior e técnico de nível médio, a exigência legal é a autodeclaração, ao passo que nos concursos públicos exige-se, complementarmente, a validação da autodeclaração por meio da heteroidentificação étnico-racial. Temos, portanto, dois procedimentos distintos para a aferição das condições de beneficiários das vagas reservadas para negros nas duas políticas públicas em exame. Isso se deve às conjunturas nas quais as duas normas foram sancionadas. Em 2012, quando a Lei $\mathrm{n}^{\circ} 12.711$ foi aprovada, ainda havia muita resistência em relação ao uso do critério racial nas políticas públicas. O que materializou-se na Arguição de Descumprimento de Preceito Fundamental (ADPF) $n^{\circ} 186$, impetrada junto ao Supremo Tribunal Federal (STF), a qual tramitou entre 2009 e 2012, e, ao final, a constitucionalidade foi $\operatorname{admitida~}^{5}$ (BRASIL, 2009). A Lei $\mathrm{n}^{\circ} 12.990$, por sua vez, foi aprovada no ano de 2014, conjuntura na qual a Suprema Corte havia se manifestado em relação às cotas nas universidades. Isso, talvez, tenha contribuído para que a previsão da heteroidentificação figurasse na normativa para os concursos públicos, ainda que de forma implícita. Porém, as cotas nos concursos públicos também foram alvo de questionamento pela Ação Declaratória de Constitucionalidade (ADC) no 41, julgada em 2017 (BRASIL, 2016e).

A polêmica gira em torno de uma suposta "dúvida" em se definir quem é negro na sociedade brasileira. Tema antigo e amplamente explorado por intelectuais e militantes. Há

\footnotetext{
${ }^{4}$ O MPOG foi incorporado ao Ministério da Economia, a partir de 2019.

5 A ADPF (Arguição de Descumprimento de Preceito Fundamental) foi impetrada pelo Partido Democratas (DEM), questionando os sistemas de cotas das universidades federais, de Brasília (UNB) e do Rio Grande do Sul (UFRGS).
} 
dentre esses, aqueles que afirmam que a nossa sociedade não tem dificuldade em distinguir quem é negro quando a finalidade é retirar direitos, ou seja, discriminar negativamente, ao passo que quando se busca discriminar positivamente, para atribuir direitos, surge a dúvida. Discriminação positiva, segundo Gomes (2005), é uma terminologia equivalente à ação afirmativa utilizada na Europa, à qual Madruga (2005, p. 50) relaciona à igualdade que "tanto é não-discriminar, como discriminar em busca de uma maior igualização. Isso se deve às características peculiares do "racismo à brasileira" (TELLES, 2003), que faz com que seja difundida uma ideia de que, no Brasil, país miscigenado, existiria uma harmonia racial que comprometeria a possibilidade de se distinguir com precisão quem seria negro ou não. Tal ideologia encontra respaldo na tese freyreana, segundo a qual entre a Casa Grande e a Senzala os senhores e os escravos se relacionavam de maneira harmoniosa (FREYRE, 2001). Esse ponto de vista foi há muito tempo contestado, no entanto, ainda está presente em nosso meio.

Como vimos, o uso do critério racial na adoção de políticas públicas foi objeto de análise na Corte Suprema e as decisões, nos dois casos, foram no sentido de que a autodeclaração e a heteroidentificação são mecanismos legítimos e adequados para assegurar o direito ao benefício das cotas raciais. Na ADPF n ${ }^{\circ}$ 186/2012 tanto a autoidentificação, quanto a heteroidentificação, são admitidos, "desde que [...] jamais deixem de respeitar a dignidade pessoal dos candidatos" (BRASIL, 2009, p. 184). Na ADC n 41/2017, lê-se que para dar concretude à política de ação afirmativa seria "legítima a utilização, além da autodeclaração, de critérios subsidiários de heteroidentificação [...] para combater condutas fraudulentas e garantir que os objetivos da política de cotas sejam efetivamente alcançados" (BRASIL, 2016e, p. 36).

Do ponto de vista histórico, a classificação racial no Brasil é realizada há mais de 140 anos e o órgão responsável pelo estabelecimento da metodologia é o IBGE. De acordo com Osório (2013, p. 87), a classificação a ser adotada:

deve idealmente ser composta pelas categorias mais difundidas e frequentes nas classificações espontâneas, e ser condizente com o tipo de informação que se visa levantar mediante a pergunta sobre cor ou raça. A classificação racial atualmente empregada pelo IBGE distingue as variedades pela característica "cor da pele", que pode ser branca, preta, amarela, parda e indígena.

Reside aí a gênese do uso atual de cinco grupos de cor/raça adotados nos inquéritos oficiais. A utilização da autodeclaração foi convencionada nas pesquisas censitárias e amostrais realizadas pelo IBGE e consideram, exclusivamente, o fenótipo como critério de atribuição do pertencimento étnico-racial. Por meio dessa metodologia, o recenseador pergunta ao entrevistado qual é a sua cor ou raça, com base nas seguintes alternativas: (i) branca, (ii) preta, 
(iii) parda, (iv) amarela ou (v) indígena ${ }^{6}$. Nesse momento, a opinião do entrevistador não pode interferir na autodeclaração, o que vale é a manifestação de quem está sendo indagado. Se seu grupo familiar tem mais pessoas, o entrevistado classifica os demais membros que residem no seu domicílio (heteroatribuição). Com essa metodologia uma pessoa preta, poderia se autodeclarar parda, ou uma parda se dizer branca, situação corriqueira nesse tipo de inquérito sociodemográfico.

Na classificação étnico-racial baseada nas cinco categorias estabelecidas pelo IBGE, os autodeclarados pretos e pardos devem ser somados, dando origem a uma categoria mais ampla denominada de negros ${ }^{7}$. Para Nascimento e Fonseca (2013), tal conceituação genérica reporta à noção de afrodescendente e "torna-se um artifício perigoso em uma sociedade marcada pela desigualdade e pelo racismo" (p. 60). Citando Fonseca (2004), os autores advertem que se trata de uma opção temerária, pois, recorre às indefinições, ou realizamos escolhas teóricas e políticas apressadas de conceitos "guarda-chuvas", os quais geram uma irmandade comum, contudo, frágil, por atuar em um universo social sem desigualdades e sem diferenças" (FONSECA, 2004 apud NASCIMENTO; FONSECA 2013, p. 60). O perigo e as fragilidades retratados pelos autores parecem estar se revelando no momento em que a autoclassificação étnico-racial é requerida, para fins de concessão de benefícios conferidos pelas cotas raciais. De tal sorte, surgem inúmeras autodeclarações oportunistas, de pessoas que socialmente não seriam alvo de racismo, visando à conquista de vagas nas instituições federais e nas carreiras públicas. Em muitos casos, o argumento que justificaria tal autodeclaração seria a afrodescendência, sendo resgatados antepassados de origem negra, ainda que posicionados em várias gerações remotas. Em geral, a alegação é a de que são descendentes da miscigenação entre pessoas brancas e pessoas pretas ou pardas, citando, por exemplo, avós e avôs como não brancos (FONTOURA, 2018). A retirada do vovô e da vovó do armário (FONTOURA, 2018) vem sendo caracterizada pelo MSN, especialmente pelos Coletivos de Estudantes Negros, como afro-conveniência.

Recorremos mais uma vez ao futebol para estabelecer uma relação com o que vem ocorrendo com as autodeclarações em tempos de cotas raciais. A primeira diz respeito ao jogador Ronaldo "Fenômeno", que em determinada ocasião, declarou-se branco, enquanto seus pais afirmavam que ele seria pardo. $\mathrm{O}$ outro exemplo se passou com o também jogador de

\footnotetext{
${ }^{6}$ Sobre esse tipo de classificação, Nascimento e Fonseca (2013, p. 51), advertem que "tecer considerações, fazer interpretações, análises e reflexões sobre as características étnico-raciais tem sido algo complexo na medida em que diversas categorias sociais são postas em concorrência e em diálogo constante, sobretudo porque trazem conceitos, palavras e terminologias estruturadas pelo imaginário europeu para estabelecer e explicar as diferenças entre os povos com a finalidade de exercer e justificar o domínio de alguns grupos sobre outros".

7 Esse procedimento usualmente adotado pelo IBGE foi incorporado ao Estatuto da Igualdade Racial (Lei $n^{\text {o }}$ 12.288/2010), que define como população negra a soma de pretos e pardos (BRASIL, 2010).
} 
futebol, Neymar Filho, à época atleta do Santos Futebol Clube. Em certa ocasião, ele afirmou nunca ter sido vítima de preconceito racial, no campo ou fora dele, e justificou: "até porque não sou preto, né?". Considerando que, na metodologia do IBGE, apenas um informante classifica a si e ao seu grupo familiar, dependendo de quem seja o respondente, o jogador Ronaldo poderia ser classificado como branco ou como pardo. Os exemplos apresentados ilustram um pouco da complexidade que envolve as classificações étnico-raciais realizadas pelo próprio indivíduo (autodeclaração) e por terceiros (heteroidentificação).

Pensando no reconhecimento étnico-racial dos jogadores Ronaldo e Neymar, no contexto do objeto de análise deste ensaio, indagamos se as pessoas com características fenotípicas como as deles, em tempos de ações afirmativas, também se reconheceriam de tal forma. Isso remete à pergunta de Rosemberg (2004, p. 62): “o branco das pesquisas do IBGE continua branco quando responde a um questionário para um programa de ação afirmativa destinado a negros e indígenas?". Mais do que nunca, tais questões reclamam por respostas. Para Rosemberg (2004, p. 61) é necessária a adoção de

\begin{abstract}
procedimentos e terminologia que vêm sendo consagrados pelo movimento negro e por acadêmicos interessados na compreensão do peso específico da categoria raça na produção de desigualdades educacionais, a saber: a autoclassificação de cor ou raça conforme sua formulação pelo IBGE; em um primeiro momento, comparação dos dados para os três segmentos de cor, branca, preta e parda; e, finalmente, a comparação dos dados a partir da composição de dois segmentos raciais, branco e negro, este último composto por pretos e pardos.
\end{abstract}

O trabalho supracitado refletia a destinação de benefícios ao Programa Internacional de Bolsas de Pós-Graduação da Fundação Ford, gerenciado pela Fundação Carlos Chagas para candidatos negros (pretos e pardos) e indígenas. Portanto, foi redigido num momento em que a discussão sobre os critérios e os procedimentos a serem adotados nas cotas raciais ainda não se colocavam no nível de preocupação atual. A despeito disso, tal análise não se torna descartável, pois, reside aí a problemática com a qual as instituições de ensino e os órgãos públicos vêm se defrontando.

Diante dessas reflexões, a pergunta que se coloca é a seguinte: dentre as cinco possibilidades de autodeclaração de cor/raça propostas pelo IBGE, qual delas vêm centralizando a problemática aqui retratada? Em resposta, diríamos, sem medo, que se tratam das autodeclarações de pessoas que se dizem pardas. Na maioria dos casos polêmicos, estão os pardos que não têm características fenotípicas de pessoas negras, ou seja, aqueles que, na sociedade brasileira, não seriam alvo do racismo estrutural. Nesse contexto, o pardo assume aquela fluidez perigosa destacada por Munanga (2004), por Fonseca (2004) e por Nascimento e Fonseca (2013). Isso porque, segundo Alves (2010): 
[...] es[s]as definições [...] não simplificam as opções das pessoas, pois, mesmo existindo uma maior facilidade para definir os extremos das cores branca e preta, o "meio de campo" fica muito indefinido. Existem muitas pessoas pretas ou brancas que poderiam facilmente ser classificadas como sendo da cor parda. Um filho de índio que viva fora de seu aldeamento terá dificuldade para se definir enquanto índio ou pardo. Um descendente de asiático que tenha alguma miscigenação poderá se classificar com amarelo ou como pardo.

\section{DAS INQUIETAÇÕES COM OS ABUSOS DA AUTODECLARAÇÃO}

A sociologia da educação revela que as desigualdades sociais relacionadas ao acesso e à permanência ao ensino superior são persistentes e enormes (NEVES, 2013). Esse é, portanto, um aspecto particular no qual pretendem incidir as políticas de ação afirmativa. Essa área de conhecimento revelou também que o valor simbólico e material de uma vaga, em certos cursos das instituições federais de ensino superior e técnicas de nível médio, é algo extremamente alto para determinados segmentos sociais. Do ponto de vista da empregabilidade, o mesmo se aplica ao acesso às carreiras do serviço público federal. Daí a relevância das políticas de ação afirmativa como estratégias de redistribuição, promoção da justiça social e combate às desigualdades, tal como alude Magnoni (2016, p. 299) pois

em se tratando de vagas nas universidades públicas, cotas, no caso brasileiro, significam uma possibilidade concreta de justiça social, de divisão de riqueza e de poder do Estado, haja vista que o acesso ao ensino superior público e gratuito ter sido até hoje privilégio (com poucas exceções) das classes médias/altas e brancas...

Conforme foi dito, as políticas de ação afirmativa beneficiam múltiplos segmentos sociais, o que Santos, Souza e Sasaki (2013) caracterizaram como subprodutos das cotas raciais, ainda assim, não restam dúvidas de que elas representam uma importante conquista do MSN. Conquista essa que demonstra o potencial da articulação desse Movimento, que foi capaz de aglutinar à sua pauta múltiplos sujeitos e grupos. Neste contexto, ao lado da Lei $\mathrm{n}^{\mathrm{o}} 10.639 / 2003^{8}$ e do Estatuto da Igualdade Racial ${ }^{9}$, destacam-se as Leis de Cotas $\left(\mathrm{n}^{\mathrm{o}}\right.$ 12.711/2012 e $\mathrm{n}^{\mathrm{o}}$ 12.990/2014). De acordo com Danilo Rosa de Lima ${ }^{10}$, nos primeiros três anos de implementação da Lei $\mathrm{n}^{\circ} 12.711 / 2012$, aproximadamente 150 mil negros ingressaram nas

\footnotetext{
${ }^{8}$ Cria a obrigatoriedade do ensino de história e cultura africana e afro-brasileira nos currículos (BRASIL, 2003).

${ }^{9}$ Objetiva "garantir à população negra a efetivação da igualdade de oportunidades, a defesa dos direitos étnicos individuais, coletivos e difusos e o combate à discriminação e às demais formas de intolerância étnica" (BRASIL, 2010).

10 Ex-Diretor do DCE/UFSCar e conselheiro municipal juventude de SP. Membro do Coletivo Nacional de Juventude pela Igualdade Racial, da Juventude Educafro, articulador do Fórum Nacional de Juventude Negra e integrante do Grupo de Estudos Étnico-Raciais da UFSCar. É também um dos articuladores nacionais do Encontro de Estudantes de Coletivos Universitários Negros (LIMA, 2015).
} 
instituições federais de ensino superior (LIMA, 2015) ${ }^{11}$. Entretanto, para além do avanço que isto possa significar, pontuou duas preocupações, que também perpassaram a pesquisa aqui retratada (SANTOS, 2018; 2020). A primeira, diz respeito às condições para a permanência, e a segunda, refere-se às fraudes nas cotas raciais. $\mathrm{O}$ foco deste ensaio é a segunda preocupação, que consiste na "necessidade urgente de se estabelecer um controle adequado na aplicação de políticas de ação afirmativa, tanto nas universidades quanto nos concursos públicos" (LIMA, 2015). Para esse autor, o Governo deveria normatizar a obrigatoriedade da adoção das comissões de validação das autodeclarações, como estratégia de enfrentamento das fraudes. Norma essa que envolvesse as instituições de ensino, em particular os gestores públicos responsáveis pela organização dos concursos, pois

se por um lado há um indivíduo mau-caráter que intencionalmente provoca danos ao direito de ação afirmativa dos estudantes negros(as) e que deve responder criminalmente por isso, por outro lado, a instituição muitas vezes é conivente e não faz efetivamente nada para evitar ou punir as fraudes. (LIMA, 2015).

Reclames semelhantes foram manifestados por estudantes que participaram da pesquisa de Santos (2018) ao afirmarem que era preciso:

fiscalizar autodeclarações de pretos, pardos e indígenas, uma vez que havia no curso de Medicina alunos que não teriam direito a essa modalidade de cotas pois, fraudam o sistema para conquistar a vaga.

estabelecer crtérios para as cotas raciais, porque existem turmas de Medicina em que pessoas claramente de etnia branca entraram utilizando cotas raciais. Ressaltando-se que elas ocuparam todas as vagas destinadas às cotas raciais. utilizar o fator fenotípico para cotas raciais (SANTOS, 2018, p. 163).

A questão das denúncias de fraudes também foi abordada com os gestores das universidades pesquisadas. Um deles alegou que os riscos estão em todas as modalidades de reservas, “o que no seu entendimento é lamentável, pois a lei foi concebida para 'reconhecer um problema histórico em vários níveis, mas infelizmente a conduta atual tem se mostrado muito problemática"” (SANTOS, 2018, p. 134). Outro gestor colocou-se favorável à constituição da comissão de heteroidentificação, ainda inexistente. Em 2017, uma dessas universidades recebeu a denúncia de que um estudante do curso de Direito que ingressou por essa cota não seria negro. A comissão constituída ${ }^{12}$ para a apuração concluiu que, de fato, o denunciado não tinha características fenotípicas de pessoa negra. Assim, recomendou o cancelamento da sua matrícula, o que foi concretizado (SANTOS, 2018). Na análise

\footnotetext{
11 Participação na Audiência Pública da Comissão Permanente de Direitos Humanos e Legislação "Cotas para negros e o conflito entre o Direito Administrativo e o Direito Constitucional" do Senado Federal, em 14 de setembro de 2015 (BRASIL, 2015).

${ }^{12}$ Composta por servidores docentes e técnicos-administrativos.
} 
documental realizada nessa IES, verificamos que a denúncia não se limitou ao caso referido, o que foi confirmado por Santos; Camilloto; Dias (2019, p. 26) ao evidenciarem que

movida pelo poder-dever da Administração Pública de apuração das denúncias que lhe são encaminhadas [...] constituiu comissões específicas para realizarem a apuração. Como resultado [...] um percentual expressivo das denúncias se confirmou, gerando como consequência o cancelamento das matrículas dos denunciados. Cerca de $80 \%$ das denúncias apuradas constataram que os denunciados de fato não eram pessoas negras, ocupando vagas reservadas para negros.

Um ano depois, a mesma instituição constituiu comissão de heteroidentificação como requisito obrigatório para todos os candidatos ingressantes pelo Sistema de Seleção Unificada (SiSU) a partir do segundo semestre de $2018^{13}$.

O desconforto institucional em ter que conviver com as denúncias de fraudes não ficou circunscrito às universidades, alvos da pesquisa do autor. No período compreendido entre 2015 e 2018, uma avalanche de notícias foi veiculada na imprensa nacional, com denúncias registradas em todas as regiões do país. Em rápida consulta à rede mundial de computadores, em relação à região sul, no ano de 2016, a Universidade Federal de Santa Maria (UFSM) foi citada em decisão do Tribunal Regional Federal da $4^{\text {a }}$ Região (TRF4), mantendo a determinação do cancelamento de matrícula de um estudante que ingressou em 2014, autodeclarando-se pardo (SUL 21, 2016). Na Universidade Federal do Rio Grande do Sul (UFRGS), em 2017, mais de 300 estudantes autodeclarados negros foram denunciados. As apurações confirmaram que a maioria estava ocupando as vagas indevidamente, tratavam-se de pessoas brancas. Para um representante do MSN local, tais estudantes excluíram do certame pessoas que seriam as verdadeiras detentoras do direito às vagas (SPERB, 2017). Esse evento teve ampla repercussão e desdobramentos, por um lado, os defensores dos acusados atribuíam caráter de "tribunal racial" às comissões de apuração, e de outro, os coletivos de estudantes negros e negras pressionando pelo afastamento dos fraudadores e das fraudadoras.

Em relação à região sudeste, identificamos que a Universidade Federal do Espírito Santo (Ufes) foi citada pelo Coletivo Negrada em denúncia de 40 casos de fraudes encaminhada ao MPF, com a alegação de que

esse número é bem maior do que possamos imaginar, já que aqui, como a maioria das universidades brasileiras, não possuem mecanismos de fiscalização. Lutar contra as fraudes nas cotas raciais no Brasil tem sido o mesmo que lutar contra o próprio racismo institucional e suas diversas facetas, pois ao invés das instituições fiscalizarem o cumprimento da lei e protegerem os direitos reservados à população negra e indígena, adotam-se os velhos argumentos racistas para deslegitimar a lei de cotas e não

13 Trata-se da mesma instituição cujo gestor havia se manifestado favorável, inicialmente, à heteroidentificação amostral. 
responsabilizar os fraudulentos pelos atos ilícitos praticados (SANTOS, 2016).

Em Minas Gerais, sete das suas doze instituições federais de ensino superior foram alvo de denúncias de fraudes nas cotas raciais. Na Universidade Federal de Minas Gerais (UFMG), no ano de 2017, as organizações de estudantes negros iniciaram um movimento de cobrança junto a Reitoria, exigindo procedimentos de validação das autodeclarações raciais de candidatos pretos, pardos e indígenas (PPI), como combate às tentativas de fraudes. Segundo Jesus (2019, p. 127), “embora a exigência de autodeclaração racial para o ingresso em um dos cursos de graduação da UFMG já vigorasse há oito anos, nunca antes se observou, tal como no ano letivo de 2017, um número tão expressivo de denúncias de fraudes na autodeclaração racial". Esse movimento ampliou-se em 2018, quando a UFMG anunciou que havia concluído a sindicância preliminar e submeteria os denunciados a processos de investigação administrativa e disciplinar (OLIVEIRA; RICCI, 2018). Na ocasião, o presidente da União de Negros e Negras pela Igualdade (Unegro/MG) afirmou que "são casos gritantes e escandalosos de uso indevido de cota racial" (OLIVEIRA; RICCI, 2018).

$\mathrm{Na}$ Universidade Federal de Uberlândia (Ufu), a provocação partiu do Ministério Público Federal (MPF) que exigiu a apuração de denúncias de fraudes. Isso resultou na criação, posteriormente, de comissão institucional para apuração de casos suspeitos e estabelecimento de regras para validação de autodeclarações de pretos, pardos e indígenas, em casos de denúncias e como procedimento regular antes da matrícula dos calouros (FONTES, 2016).

$\mathrm{Na}$ Universidade Federal de Viçosa (UFV), foi também em resposta ao MPF que se deu a constituição, em 2016, de comissão especial para apuração de eventuais fraudes, relacionadas a 51 casos, dos quais, 26 se confirmaram, e como resultado houve o desligamento das matrículas (ALBERTO, 2017). A partir de 2017, a UFV tornou a heteroidentificação obrigatória nos processos seletivos do SiSU.

Outra universidade que foi alvo de denúncias, cuja repercussão ultrapassou os muros do campus, foi a Universidade Federal de Juiz de Fora (UFJF). Em 2018, a Instituição de Ensino Superior (IES) recebeu 92 denúncias e acolheu 17, as quais foram apuradas, por meio de Processo Administrativo Disciplinar (PORTAL G1 ZONA DA MATA, 2018). De acordo com nota divulgada, pela UFJF, das 92 denúncias, 12 diziam respeito a estudantes cujos nomes figuravam na lista de espera, portanto, ainda não alunos. Oito haviam sido convocados, porém, não efetuaram as matrículas, três solicitaram cancelamento tão logo foram notificados e um dos denunciados não constava da lista de aprovados. Assim, a apuração da comissão foi em relação a 68 estudantes. O resultado dos trabalhos concluiu que 51 eram pardos, e em 17 casos, as fraudes se confirmaram (UFJF, 2018). 
Na Universidade Federal de Ouro Preto (Ufop), as denúncias também se iniciaram em 2017. A partir da edição do $2^{\circ}$ semestre do SiSU de 2018, todos os candidatos ingressantes pelas reservas de vagas para negros (pretos e pardos) passaram a ser submetidos à heteroidentificação. No ato da matrícula, eles apresentam dois documentos de autodeclaração, um dos quais justificado. Ademais, vem explicitado nos regulamentos e nos formulários aplicados, que para comprovação das condições de beneficiários das vagas reservadas para PPI, ao selecionar a opção preto ou pardo, os candidatos assumem-se negros. Tal condição é estabelecida no edital o qual explicita as reservas de vagas de corte étnico-racial para negros (pretos ou pardos) e indígenas.

A utilização de instrumentos complementares de verificação ou de validação da autodeclaração foi caracterizada por Rosemberg (2004) como prática de triangulação. É uma importante estratégia para evitar que não negros ultrapassem a linha da cor. Essa metodologia tem como objetivo evitar injustiças e o oportunismo, entretanto, ao incluir determinadas perguntas nos formulários utilizados não se pretende violentar o candidato. O que se procura é, partindo da presunção de veracidade da autodeclaração, estimulá-lo a refletir se é de fato destinatário da política pública, isso porque não se sabe, a priori, se "todos candidatos que se declararam negros ou indígenas assim seriam considerados pela sociedade ou que se autoclassificariam como negros e indígenas ou não-brancos fora do processo de seleção...” (ROSEMBERG, 2004, p. 63-64) ${ }^{14}$.

A Universidade Federal de Lavras, por sua vez, viu-se às voltas com este tipo de denúncia no ano de 2017, ocasião em que um telejornal local noticiou: "Universidade Federal de Lavras investiga alunos por uso indevido de cotas étnico-raciais" e que se encontrava investigando seis alunos por terem usado indevidamente as cotas étnico-raciais, após serem denunciados (JORNAL DA EPTV 1ª EDIÇÃO, 2017). Não encontramos informações sobre os resultados da apuração, por parte da comissão de sindicância, que teria 30 dias para conclusão dos trabalhos. A informação que dispomos é a de que, a partir de 2018, a IES instituiu as comissões de heteroidentificação no seu processo seletivo. De acordo com o termo de adesão do SiSU, edição do $1^{\mathrm{o}}$ semestre de 2019 , todos os candidatos autodeclarados pretos, pardos e indígenas deveriam inserir, em sistema próprio, no ato da matrícula uma foto digitalizada,

tirada de frente, com fundo limpo, não podendo ser feita com qualquer espécie de cobertura na cabeça (lenço, chapéu, boné), nem com óculos de sol, que dificultem ou encubram as características físicas, imprescindíveis para a averiguação, pela Comissão nomeada pelo Reitor, que julgará ser procedente (UFLA, 2018).

\footnotetext{
${ }^{14}$ Lembremos do exemplo supracitado acerca dos jogadores Ronaldo e Neymar.
} 
Consulta realizada pelo jornal $O$ Tempo constatou que, na Universidade Federal de Alfenas (UNIFAL), havia registro de denúncias, algumas apuradas e sem confirmação das fraudes e outra em andamento (DINIZ; MANSUR, 2017). Não conseguimos informações sobre o resultado desta última, porém, de acordo com o Edital do SiSU, verificamos que a IES realiza procedimentos de heteroidentificação desde o $1^{\circ}$ semestre de 2018.

No levantamento que realizamos não encontramos registros de denúncias relacionados às universidades federais: do Triângulo Mineiro (UFTM), de São João del-Rei (UFSJ), de Itajubá (UNIFEI) e dos Vales do Jequitinhonha e Mucuri (UFVJM), tampouco do Centro Federal Tecnológico de Minas Gerais (CEFET-MG). Com relação a essa última instituição, cumpre destacar que ela tem demonstrado um importante compromisso com o controle da adequada ocupação das vagas destinadas aos PPI estabelecidas pela Lei no 12.711/2012. Além disso, no ano de 2018, o CEFEF-MG sediou um encontro de coordenadores de processos seletivos das instituições mineiras, no qual o tema foi pautado. Inclusive contou com a participação do Promotor Helder Magno da Silva, da Comissão de Defesa do Cidadão do MPF/MG. Desde o primeiro semestre letivo de 2018, o CEFET-MG passou a adotar a heteroidentificação étnico-racial.

No Estado do Rio de Janeiro, as denúncias de abusos no uso das cotas raciais foram registradas, inicialmente, na Universidade Federal do Estado do Rio de Janeiro (Unirio) e na Universidade Federal Fluminense (UFF). A Unirio foi alvo de matéria veiculada no Fantástico, em 2016, segundo a qual "Estudantes fingem ser cotistas para entrarem em universidades públicas" (FANTÁSTICO, 2016). Posteriormente, as duas instituições incorporaram os processos de heteroidentificação no recrutamento. Outro dado importante foi uma audiência pública que o MPF realizou, em 2017, para a qual convidou a Unirio, a Universidade Federal Rural do Rio de Janeiro (UFRRJ), a Universidade Federal do Rio de Janeiro (UFRJ) ${ }^{15}$ e o Instituto Federal de Ciência e Tecnologia do Rio de Janeiro (IFRJ). O objetivo foi discutir a aplicação da Lei ${ }^{0}$ 12.711/2012, no que diz respeito aos critérios para atribuição do direito às cotas raciais (BRASIL, 2017). Na ocasião, a representante da Procuradoria Regional dos Direitos do Cidadão (MPF/RJ) discorreu sobre a

importância de se combaterem as fraudes que vêm ocorrendo com relação às cotas para negros para acesso às universidades. Não raro, os candidatos de cor branca que se autodeclaram negros são ideologicamente contrários às cotas, e se utilizam deste artifício como forma de demonstrar que as cotas não deveriam existir e prejudicam aqueles que delas necessitam (BRASIL, 2018b).

\footnotetext{
${ }^{15}$ Em 2018, a IES realizou uma capacitação sob coordenação da SEPPIR.
} 
Como resultado, no ano seguinte, o MPF/RJ publicou uma recomendação, segundo a qual essas instituições deveriam adotar mecanismos de controles prévios visando "a aferição dos requisitos para o ingresso ao ensino superior por meio das cotas raciais reservadas, com adoção prioritária do critério do fenótipo, ou seja, da aparência” (BRASIL, 2018b).

Em relação ao Estado de São Paulo, o jornalista Luiz Fernando Antunes Toledo encaminhou, no ano de 2016, requerimentos através do Sistema Eletrônico do Serviço de Informação ao Cidadão, às universidades federais de São Paulo (Unifesp), do ABC (UFABC) e de São Carlos (Ufscar), solicitando o número total de sindicâncias instauradas para apurar possíveis fraudes em aprovações de alunos por cotas raciais, ano a ano (desde o início da política de cotas (TOLEDO, 2016).

Em resposta, a Unifesp informou que "não houve sindicâncias instauradas referentes a cotas raciais - fraudes" (UNIFESP, 2016). A Ufscar respondeu que "nunca houve [...] a instauração de sindicâncias para apurar possíveis fraudes..." (TOLEDO, 2016). Antes da vigência da Lei $\mathrm{n}^{\circ}$ 12.711/2012, a Ufscar havia desligado uma aluna que fraudou as cotas para indígenas (UFSCAR, 2012). Importante ressaltar que essa IES adotou uma política de ação afirmativa no ano de 2007 e, à época, previa "que o ingresso de pessoas negras (pretas e pardas) se daria por autodeclaração e, concomitantemente, que a instituição poderia 'a qualquer momento, verificar a veracidade das informações prestadas pelo candidato"” (UFSCAR, $2017)^{16}$.

No que se refere à UFABC, Toledo (2016) requereu, entre outras informações, “o número total de sindicâncias instauradas para apurar possíveis fraudes em aprovações por cota, ano a ano, informando quantas, de fato, resultaram em punição ao aluno (indicando a punição aplicada)". Em resposta, a Pró-Reitoria de Graduação informou que houve apenas uma sindicância, relacionada ao critério de renda, e que se confirmou "que houve omissão de documentação no ato da matrícula e a matrícula do candidato foi anulada" (TOLEDO, 2016).

$\mathrm{Na}$ região nordeste a maior parte das informações encontradas sobre fraudes se relacionavam à Bahia e envolviam as universidades federais da Bahia (UFBA), do Recôncavo (UFRB) e do Sul (UFSB). Na Ufba, as denúncias são antigas, retrocedem ao ano de $2006^{17}$, ano em que a imprensa veiculou notícias a esse respeito (ESTADO DE SÃO PAULO, 2006; JORNAL A TARDE, 2006; FOLHA ONLINE, 2006). Posteriormente, no ano de 2014, a IES foi novamente citada em denúncia relativa à fraude em vagas reservadas para quilombolas e indígenas. Na vigência da Lei de Cotas, em 2017, o MPF questionou a Universidade e exigiu posicionamento em relação a denúncias de fraudes de egresso do curso de Bacharelado

\footnotetext{
${ }^{16}$ Nos termos da Portaria GR n ${ }^{\circ} 695 / 07$.

${ }^{17}$ Muito antes da Lei de Cotas.
} 
Interdisciplinar (BI) ${ }^{18}$ de Humanidades, visando o ingresso no curso de Direito. Segundo o Correio de Salvador, esse "foi o ponto de partida para mostrar um universo de possíveis fraudes ainda maior: hoje, a suspeita é de que pelo menos 25 estudantes estejam ocupando vagas que não deveriam ser suas" (CORREIO DE SALVADOR, 2017).

Na UFSB, uma denúncia de fraude encaminhada por um estudante se desdobrou numa grande polêmica. Ultrapassou os limites da esfera institucional e se converteu em conflito pessoal, envolvendo o denunciante e um gestor da IES, que teve o nome da sua esposa arrolado entre o dos fraudadores. Os desdobramentos de uma postagem nas redes sociais ganharam dimensão expressiva e trouxeram à baila essa celeuma. Aspecto que nos interessa, neste particular, é o fato de estarmos diante de mais uma instituição que é alvo de denúncias. Segundo matéria publicada pelo portal Ipiaú Online, as fraudes teriam ocorrido na transição dos estudantes dos ciclos dos bacharelados interdisciplinares para os profissionalizantes (seriam mais de uma centena de casos). Tais denúncias mobilizaram a IES, que decidiu adotar procedimentos para apuração, bem como envolveu o MPF e, até mesmo, ação particular na Justiça, envolvendo o agente institucional contra o estudante denunciante (ROMMEL, 2018).

No Estado de Alagoas, no ano de 2016, o MPF/AL cobrou posicionamento da Universidade Federal de Alagoas (Ufal) em relação às denúncias de fraudes nas cotas raciais e indagou por que a IES não contava com mecanismos que realizassem a validação da autodeclaração étnico-racial. A Universidade admitiu a possibilidade de brancos terem se autodeclarado negros no processo seletivo do SiSU daquele ano. A denunciante alegou ao Portal 7 Segundos que

[...] vagas reservadas estão sendo preenchidas por pessoas de cor branca, o que caracteriza fraude em concurso público. Ademais, questionada acerca da verificação de um candidato ao grupo étnico por ele declarado, a instituição disse não possuir autonomia para julgar algo tão subjetivo (PORTAL 7 SEGUNDOS, 2016).

À época, a Ufal alegou que a Lei de Cotas não previu procedimentos complementares à autodeclaração, ato por meio do qual o candidato se diz preto, pardo ou indígena, no momento da matrícula (PORTAL 7 SEGUNDOS, 2016). Justificando-se, assim, o fato de a Ufal não realizar algo além disso. Constatamos, porém, que a partir do ano de 2018, a heteroidentificação foi incorporada, por ocasião de um processo administrativo de denúncia de fraude na autodeclaração do candidato aprovado em primeiro lugar em concurso para servidor dessa IES, cabendo ao Núcleo de Estudos Afro-Brasileiros (Neab), atual Núcleo de Estudos Afro-

\footnotetext{
18 Bacharelado Interdisciplinar (BI) é uma modalidade de curso de graduação, com fase inicial comum e terminalidades específicas. Ao final da fase inicial, os estudantes optam ou não por carreira profissional específica a ser complementada.
} 
brasileiros e Indígenas (NEABI) coordenar a validação da autodeclaração étnico-racial dos candidatos a partir desse episódio (UFAL, 2019). Importante ressaltar que esse destaque, demonstra um reconhecimento do Neabi como órgão institucional responsável e habilitado para esse fim.

De Pernambuco, a notícia que encontramos foi a de que a Universidade Federal de Pernambuco (UFPE) abriu procedimento para investigação de 17 denúncias de fraudes, relacionadas aos critérios racial e de renda no SiSU 2018. Assim, a IES constituiu comissão para as devidas apurações e confirmou ao Diário de Pernambuco a ocorrência de 11 casos de estudantes envolvendo autodeclarações de PPI. Além disso, a UFPE anunciou que estudaria a possibilidade de institucionalização da heteroidentificação a partir do SiSU 2019. A Universidade também vem fazendo gestões junto à Associação Nacional dos Dirigentes das Instituições Federais de Ensino Superior (Andifes), no sentido "da criação de procedimentos padronizados referentes às cotas a serem adotados por todas as instituições federais do país" (DIÁRIO DE PERNAMBUCO, 2018). O compromisso de adoção da heteroidentificação, a partir de 2019, foi cumprida, e encontra-se regulamentada no item 7 do Edital do Processo Seletivo UFPE - SiSU 2019 (UFPE, 2018).

Em levantamento realizado pelo Estadão, em janeiro de 2018, a região norte teve quatro IES dentre as que estiveram envolvidas com casos de fraudes. A do Amazonas (Ufam) foi a que liderou o ranking, contabilizando quatro casos. As universidades federais do Acre (Ufac), de Roraima (UFRR) e de Tocantins (UFT) compuseram o total de instituições da região mencionadas. Em cada uma delas, foram registradas suspeitas de fraude às cotas raciais (TOLEDO, 2018).

Na região centro-oeste, por sua vez, as denúncias que encontramos são de 2018 e se referem às universidades federais de Mato Grosso (UFMT), de Mato Grosso do Sul (UFMS) e de Grande Dourados (UFGD). Na UFMT, a acusação foi a de que brancos estariam fraudando as cotas nos cursos de Medicina e Direito. Em entrevista ao O Livre, Zizele Ferreira dos Santos caracterizou como afro-conveniência:

Situações em que pessoas brancas se dizem negras quando isto lhe é positivo. O Brasil é um país que nega a formação identitária negra em suas raízes. Mas nestas horas, quando a pessoa vê a vantagem, ela se torna negra com mais facilidade. Mas quando você conversa com essa pessoa, percebe que ela não se vê como negra: é apenas quando ela tem como usufruir o direito do outro. (AGUIAR, 2018).

Tal como a maioria das IES, só recentemente a UFMT passou a praticar a heteroidentificação como procedimento obrigatório nos processos seletivos da graduação. 
As denúncias relativas à UFMS foram apresentadas por estudantes do curso de Medicina, que entregaram à Polícia Federal (PF) uma listagem com 23 nomes de supostos fraudadores das cotas raciais, por renda e de pessoas com deficiência. Para os denunciantes, recorrer à PF e ao MPF deveu-se à inércia da Instituição em fazer as apurações. Segundo eles, pessoas brancas estavam ingressando nas cotas raciais e outras com situações econômicas que lhes permitiam morar sozinhas em apartamentos de alto custo, pagando mensalidades expressivas para festa de formatura. No MPF, as denúncias foram objeto de inquérito, investigados pela Procuradoria Regional dos Direitos do Cidadão (PRDC) e, paralelamente, a UFMS anunciou a instituição de comissões de heteroidentificação para reprimir eventuais fraudes, que foram implementadas, em 2017, e a partir da segunda edição do SiSU de 2018, como procedimento obrigatório.

A UFGD, por seu turno, acolheu recomendação do MPF/MS visando à realização de heteroidentificação como estratégia de combate a possíveis fraudes na ocupação das vagas reservadas pelo critério étnico-racial. "Até então, a UFGD não contava com nenhuma comissão para avaliar a autenticidade das declarações feitas pelos candidatos, o que impedia que houvesse um controle em relação a fraudes no ingresso de alunos" (BRASIL, 2018c). Em resposta, a IES adotou as bancas de heteroidentificação nos processos seletivos para os cursos de graduação. Essa polêmica voltou ao centro das atenções no ano de 2019, quando estudantes desligados foram reintegrados, com base em decisão da reitoria. Em Nota Pública, a Universidade assim se expressou:

A UFGD esclarece os motivos que levaram à reintegração de alunos excluídos do curso de Medicina por sistema de cotas, que na Universidade é de critério social. O retorno dos acadêmicos se deu através do termo de composição extrajudicial firmado com a mediação do Ministério Público Federal, assinado pelo Procurador da República, Eduardo Gonçalves (UFGD, 2019).

Ainda, na região centro-oeste, a UFG realizou uma audiência pública com os objetivos de debater a aplicação das cotas, publicizar a implementação da política pública e os critérios que adotaria no processo de heteroidentificação (ANDIFES, 2018).

Instituições aqui não mencionadas não necessariamente receberam denúncias, trata-se tão somente dos limites da pesquisa aqui empreendida. Numa perspectiva mais ampla, merece destaque o fato de que no caso da Lei $\mathrm{n}^{\mathrm{o}} 12.711 / 2012$, desde o início do seu processo de implementação, as instituições vinham sendo pressionadas pelo MSN, coletivos de estudantes negros, imprensa e outros segmentos, quanto à suposta ocupação indevida das vagas destinadas aos negros (pretos e pardos) e indígenas. Especificamente, em relação aos primeiros, denúncias eram apresentadas dando conta de que as vagas vinham sendo ocupadas por pessoas que, fenotipicamente, não seriam identificadas como negras. 
Desse breve registro, observa-se que as denúncias de fraudes ocorreram na maioria das universidades, confirmando a constatação de Jesus (2019), segundo o qual "embora o debate sobre negritude seja muito antigo no Brasil, remontando ao final do século XIX, o debate sobre quem pode (quer) ser negro no Brasil ganhou mais destaque no século XXI [...]”, com o advento das cotas raciais e as referidas denúncias de fraudes.

Não basta sentir-se negro, é necessário ser socialmente reconhecido como tal. Essa formulação encontra respaldo, entre outros, em Guimarães (2005), Nogueira (2007) e Bicudo (2010), que constataram que o racismo praticado no Brasil é peculiar. Não se compara com as experiências dos EUA e da África do Sul, por exemplo. Nesses contextos, prevalece a Lei de uma gota de sangue (One-drop rule) que determina a discriminação racial, negativa ou positiva, ao passo que, no nosso país, o preconceito racial é de marca e não de origem. De tal sorte, a classificação dos negros e das negras no Brasil se baseia na aparência física dos indivíduos (GUIMARÃES, 2005). É, pois, esse o contexto no qual se inserem as denúncias de fraudes que agitaram e continuam agitando as gestões das instituições. No cerne delas encontra-se o indivíduo que se autodeclara pardo, no entanto, cotidianamente rejeita a condição de negro. Aquele que, para Mungana (2004, p. 96), encontra-se na zona vaga e flutuante, cujo "sonho de realizar um dia o 'passing' que neles habita [e] enfraquece o sentimento de solidariedade com os negros indisfarçáveis". Nesse caso, estamos diante de muitos mestiços ou pardos que, em analogia ao futebol, seriam os ditos "gatos".

\section{REFLEXÕES FINAIS DA LEI DE GÉRSON NAS LEIS DE COTAS BRASILEIRAS}

Idealmente, a autodeclaração deveria ser o procedimento exclusivo para assegurar o direito aos benefícios das políticas de ação afirmativa com recorte racial. Posição essa respaldada pelo Movimento Social Negro durante muito tempo. No entanto, o que o processo de implementação das Leis de Cotas vem demonstrando é que o uso exclusivo da autodeclaração tem facultado a alguns "espertalhões", aqueles adeptos da Lei de Gérson, autodeclararem-se negros (pretos e pardos) ou indígenas, mesmo não o sendo, para poderem acessar um direito que, em tese, não seria seu.

No Brasil, país onde as desigualdades são abissais e raras as oportunidades para a ocupação de posições de destaque, as políticas de ação afirmativa se impõem como uma necessidade. Isso porque as políticas universalistas não foram e não são capazes de promover a democratização das possibilidades. Nesse contexto, quando o legislador elegeu determinados segmentos sociais como destinatários das políticas de cotas raciais, a expectativa era a de que as pessoas que, na sociedade, são vítimas do racismo e do preconceito pudessem acessar o 
ensino superior e técnico de nível médio e os cargos públicos. Daí a necessidade de se refletir sobre quem realmente são as pessoas que sofrem o racismo na sociedade brasileira.

À luz das contribuições de Guimarães (2005), Nogueira (2007) e Bicudo (2010) não resta dúvida de que a discriminação racial no Brasil se baseia na cor da pele. A diferença entre o racismo de cor e o de ascendência reside em variadas construções histórico-sociais da raça, que devem servir de base para o estabelecimento de quem teria o direito à redistribuição promovida pelas políticas de ação afirmativa no Brasil, conforme Ikawa (2008). No contexto em que vigora o racismo de marca é, portanto, o negro, que nele é o sujeito da discriminação racial, o destinatário dessas políticas afirmativas. Lembrando que, segundo Guimarães (2005, p. 51), no caso do Brasil, são principalmente as pessoas com a pele escura as que "sofrem inteiramente a discriminação e o preconceito".

Assim, antes de se candidatarem a tais vagas, as pessoas deveriam fazer uma autoreflexão e se indagar se são as reais destinatárias. Têm sido muito comum nas comissões de validação da veracidade da autodeclaração, argumentos relacionados à ascendência dos candidatos, tais como: "meu avô era negro, sendo assim eu tenho direito a essa vaga". Entretanto, o candidato à vaga não era o referido avô. Não partimos da premissa de que todos os candidatos nessa condição sejam fraudadores, há muita gente desinformada, dado o tabu que enreda o tema. Entretanto, há também muitos com plena consciência da sua condição étnicoracial, mas tentam se utilizar das reservas de vagas à luz da ideologia do "levar vantagem". Lembrando que uma vaga numa universidade pública, bem como a detenção de um cargo público, são bens raros na nossa sociedade desigual.

Acreditamos que a heteroidentificação cumpre o papel pedagógico de motivar os candidatos à reflexão que sugerimos anteriormente, no contexto da educação para/das relações étnico-raciais, conforme a Lei $\mathrm{n}^{\circ} 10.639 / 2003$ (BRASIL, 2003) e suas diretrizes (BRASIL, 2004). Além disso, assegura a destinação das vagas reservadas aos verdadeiros destinatários, contribuindo para reduzir as desigualdades que separam brancos e não brancos. Caso contrário, mantida a omissão, a reivindicação histórica do MSN não se concretizará e as políticas públicas terão o seu alcance reduzido, com muitos pardos "gatos" se passando por negros, fazendo prevalecer a Lei de Gérson.

\section{REFERÊNCIAS}

AGUIAR, Ednilson. Candidatos brancos são acusados de fraudar cotas raciais na UFMT. $O$ Livre, Cuiabá/MT, 08 fev. 2018. Disponível em: https://olivre.com.br/candidatos-brancossao-acusados-de-fraudar-cotas-raciais-na-ufmt-2/. Acesso em: 10 dez. 2018.

ALBERTO, Fellype. UFV identifica fraudes em autodeclarações e alunos cotistas são desmatriculados. Portal G1 Zona da Mata. Juiz de Fora/MG, 9jul2017. Disponível em: 
https://g1.globo.com/mg/zona-da-mata/noticia/ufv-identifica-fraudes-em-autodeclaracoes-ealunos-cotistas-sao-desmatriculados.ghtml. Acesso em: 10 jul. 2017.

ALVES. José Eustáquio Diniz. A Definição De Cor/'Raça' do Ibge. Ecodebate, 28 de junho de 2010. Disponível em: https://www.ecodebate.com.br/2010/06/28/a-definicao-de-corracado-ibge-artigo-de-jose-eustaquio-diniz-alves/. Acesso em: 13 maio 2016.

ANDIFES. Associação Nacional dos Dirigentes das Instituições Federais de Ensino Superior. $U F G$ - Audiência pública debate cotas raciais na universidade, Brasília/DF, 29 out. 2018. Disponível em: http://www.andifes.org.br/ufg-audiencia-publica-debate-cotas-raciais-nauniversidade. Acesso em: 18 dez. 2018.

BICUDO, Virgínia Leone. Atitudes raciais de pretos e mulatos em São Paulo. São Paulo, Sociologia e Política, 2010.

BRASIL. Decreto Lei no 2.848, de 7 de dezembro de 1940. Código Penal. Disponível em: http://www.planalto.gov.br/ccivil_03/Decreto-Lei/Del2848.htm. Acesso em: 29 dez. 2018.

BRASIL. Lei $n^{\circ}$ 10.639. Altera a Lei no 9.394, de 20 de dezembro de 1996, que estabelece as diretrizes e bases da educação nacional, para incluir no currículo oficial da Rede de Ensino a obrigatoriedade da temática "História e Cultura Afro-Brasileira", e dá outras providências. Brasília, 9 jan. 2003. Disponível em: http://www.planalto.gov.br/ccivil_03/leis/2003/110.639.htm. Acesso em: 21 ago. 2010.

BRASIL. Diretrizes Curriculares Nacionais para a Educação das Relações Étnico-Raciais e para o Ensino de História e Cultura Afro-Brasileira e Africana. Brasília, CNE/MEC, 2004. Disponível em: http://portal.mec.gov.br/busca-geral/323-secretarias-112877938/orgaosvinculados-82187207/12988-pareceres-e-resolucoes-sobre-educacao-das-relacoes-etnicoraciais. Acesso em: 21 ago. 2010.

BRASIL. Supremo Tribunal Federal. Arguição de Descumprimento de Preceito Fundamental $n^{\circ}$ 186. Brasília, 31 jul. 2009. Disponível em:

http://www.stf.jus.br/arquivo/cms/noticiaNoticiaStfArquivo/anexo/ADPF186.pdf. Acesso em 2 dez. 2018.

BRASIL. Lei $n^{o}$ 12.288. Dispõe sobre o Estatuto da Igualdade Racial. Brasília, 20 jun. 2010. Disponível em: http://www.planalto.gov.br/ccivil_03/_ato20072010/2010/lei/112288.htm Acesso em: 21 set. 2015.

BRASIL. Lei $N^{o} 12.711$, de 29 de agosto de 2012. Dispõe sobre o ingresso nas universidades federais e nas instituições federais de ensino técnico de nível médio e dá outras providências. Disponível em: http://www.planalto.gov.br/ccivil_03/_ato2011-2014/2012/lei/112711.htm. Acesso em: 20 dez. 2014.

BRASIL. Lei $n^{\circ} 12.990$, de 9 de junho de 2014. Reserva aos negros $20 \%$ (vinte por cento) das vagas oferecidas nos concursos públicos para provimento de cargos efetivos e empregos públicos no âmbito da administração pública federal, das autarquias, das fundações públicas, das empresas públicas e das sociedades de economia mista controladas pela União. Disponível em: http://www.planalto.gov.br/ccivil_03/_ato20112014/2014/lei/112990.htm. Acesso em: 21 maio 2016.

BRASIL. Senado Federal. Ata da $79^{a}$ Reunião (Extraordinária) da Comissão Permanente de Direitos Humanos e Legislação. Audiência Pública: Cotas para negros e o conflito entre o Direito Administrativo e o Direito Constitucional. Brasília, 14 set. 2015.

BRASIL. Coordenadoria de Aperfeiçoamento de Pessoal/MEC. Portaria Normativa $n^{\circ} 13$, de 11 de maio de 2016a. Dispõe sobre a indução de Ações Afirmativas na PósGraduação, e dá outras providências. Brasília/DF. Disponível em: capes.gov.br. Acesso em: 13 set. 2017. 
BRASIL. Lei $n^{\circ} 13.409$, de 28 de dezembro de 2016b. Altera a Lei no 12.711, de 29 de agosto de 2012, para dispor sobre a reserva de vagas para pessoas com deficiência nos cursos técnico de nível médio e superior das instituições federais de ensino. Disponível em:

http://www.planalto.gov.br/ccivil_03/_ato20152018/2016/1ei/L13409.htm. Acesso em: 29 dez. 2016.

BRASIL. Ministério do Planejamento, Desenvolvimento e Gestão. Secretaria de Gestão de Pessoas e Relações do Trabalho no Serviço Público. Orientação Normativa $n^{\circ} 3$, de 01 ago. 2016c. Disponível em:

http://www.trtsp.jus.br/geral/tribunal2/ORGAOS/Min_Div/MPOG_ON_03_16.html. Aceso em: 04 mar. 2018.

BRASIL. Conselho Nacional do Ministério Público. Recomendação $n^{\circ} 41$, de 9 de agosto de 2016d. Define parâmetros para a atuação dos membros do Ministério Público brasileiro para a correta implementação da política de cotas étnicoraciais em vestibulares e concursos públicos. Brasília. Disponível em:

https://www.cnmp.mp.br/portal/images/Normas/Recomendacoes/RECOMENDAO_41.pdf. Acesso em: 04 mar. 2018.

BRASIL. Supremo Tribunal Federal. Ação Declaratória de Constitucionalidade $n^{\circ} 41$. Brasília, 26 jan. 2016e. Disponível em: http://portal.stf.jus.br/processos/downloadPeca.asp?id=314272794\&ext=.pdf. Acesso em: 2 dez. 2018.

BRASIL. Ministério Público Federal do Rio de Janeiro. Audiência Pública: Ações Afirmativas para a Igualdade Racial: critérios de aferição do direito às cotas para acesso ao ensino superior no sistema federal. Rio de Janeiro, 27 out. 2017. Disponível em:

http://www.mpf.mp.br/rj/sala-de-imprensa/docs/pr-rj/ata-audiencia-publica-cotas. Acesso em: 21 dez. 2018.

BRASIL. Decreto $n^{\circ} 9.427,28$ de junho 2018a. Reserva aos negros trinta por cento das vagas oferecidas nas seleções para estágio no âmbito da administração pública federal direta, autárquica e fundacional. Disponível em:

http://www.planalto.gov.br/ccivil_03/_ato20152018/2018/Decreto/D9427.htm. Acesso em: 22 fev. 2019.

BRASIL. Ministério Público Federal do Rio de Janeiro. MPF/RJ quer adoção de controle prévio para ingresso nas cotas raciais em universidades públicas. Rio de Janeiro, 12 mar. 2018b. Disponível em: http://www.mpf.mp.br/rj/sala-de-imprensa/noticias-rj/MPF/rj-queradocao-de-controle-previo-para-ingresso-nas-cotas-raciais-em-universidades-publicas. Acesso em: 21 dez. 2018.

BRASIL. Ministério Público Federal de Mato Grosso do Sul. UFGD acata recomendação do MPF e passa a avaliar autodeclarações relacionadas ao ingresso de alunos cotistas. Campo Grande/MS, 7 de março de 2018c. Disponível em: http://www.mpf.mp.br/ms/sala-deimprensa/noticias-ms/ufgd-acata-recomendacao-do-mpf-e-passa-a-avaliar-autodeclaracoesrelacionadas-ao-ingresso-de-alunos-cotistas. Acesso em: 3 jan. 2019.

CARVALHO, Antonio Sérgio Alfredo. Racismo e anti-racismo no Brasil. São Paulo; Fundação de Amparo à Pesquisa de São Paulo/Edições 34, 2005.

CORREIO DE SALVADOR. Cotas sob suspeita 25 alunos da Ufba podem ter fraudado sistema que beneficia estudantes negros e pardos, Salvador, 31 ago. 2017. Correio 24 horas. Disponível em: https://www.correio24horas.com.br/noticia/nid/cotas-sob-suspeita-25-alunosda-ufba-podem-ter-fraudado-sistema-que-beneficia-estudantes-negros-e-pardos/. Acesso em: 14 dez. 2018. 
DIÁRIO DE PERNAMBUCO. UFPE investiga denúncias de fraude nos ingressos via cotas no SiSU 2018. Recife/PE, 04 abr. 2018. Disponível em:

http://www.diariodepernambuco.com.br/app/noticia/vidaurbana/2018/04/04/interna_vidaurbana,747481/ufpe-investiga-denuncias-de-fraude-nosingressos-via-cotas-no-sisu-201.shtml. Acesso em: 09 dez. 2018.

DINIZ, Aline; MANSUR, Rafaela. Irregularidades são apuradas em Ouro Preto e Alfenas. $O$ Tempo, Belo Horizonte, 27 set. 2017. Disponível em:

https://www.otempo.com.br/cidades/irregularidades-sao-apuradas-em-ouro-preto-e-alfenas1.1524829. Acesso em: 2 fev. 2018.

ESTADO DE SÃO PAULO. Mais um caso de fraude no sistema de cotas raciais da UFBA, 13 fev. 2006. Estado de São Paulo. Disponível em:

https://educacao.estadao.com.br/noticias/geral,mais-um-caso-de-fraude-no-sistema-de-cotasraciais-da-ufba,20060213p65819. Acesso em: 21 ago. 2014.

FANTÁSTICO. Estudantes fingem ser cotistas para entrarem em universidades públicas, 16 out. 2016. Disponível em: http:/g1.globo.com/fantastico/noticia/2016/10/estudantes-fingemser-cotistas-para-entrarem-em-universidades-publicas.html. Acesso em: 20 jan. 2017.

FOLHA ONLINE. Alunos fraudam o sistema de cotas na Bahia, 18 jan. 2006. Disponível em: https://www1.folha.uol.com.br/folha/dimenstein/cbn/capital_180106.htm. Acesso em 21 ago. 2014.

FONSECA, Dagoberto. A (re)invenção do cidadão de cor e da cidadania. Cadernos do CEAS, Salvador: Centro de Estudos e Ação Social CEAS, n. 210, p. 65-83, mar./abr. 2004.

FONTES, Letícia. Federal de Uberlândia apura suposta fraude em cotas raciais. Belo Horizonte/MG, 25 de outubro de 2016. O Tempo. Disponível em:

https://www.otempo.com.br/cidades/federal-de-uberl\%C3\%A2ndia-apura-suposta-fraude-emcotas-raciais-1.1390369. Acesso em: 12 dez. 2018.

FONTOURA, Maria Conceição Lopes. Tirando a vovó e o vovô do armário. In: DIAS, Gleidson Renato Martins; TAVARES JUNIOR, Paulo Roberto Faber. Heteroidentificação e cotas raciais: dúvidas, metodologias e procedimentos. Canoas, IFRS, 2018. p. 42-139.

FREYRE, Gilberto. Casa Grande \& Senzala. Rio de Janeiro: Record, 2001.

GOMES, Joaquim Benedito Barbosa. A recepção do instituto da ação afirmativa pelo direito constitucional brasileiro. In: SANTOS, Sales Augusto dos. Ações afirmativas e combate ao racismo nas Américas. Brasília: Ministério da Educação, Secretaria de Educação Continuada, Alfabetização e Diversidade, 2005. p. 47-82.

GOMES, Nilma Lino. O movimento negro educador. Saberes construídos nas lutas por emancipação. Petrópolis: Vozes, 2017.

IKAWA, Daniela. Ações afirmativas em universidades. Rio de Janeiro: Lumen Juris, 2008.

JESUS, Rodrigo Ednilson de. Autodeclaração e heteroidentificação racial no contexto das políticas de cotas: quem quer (pode) ser negro no Brasil? In: SANTOS, Juliana Silva; COLEN, Natália Silva; JESUS, Rodrigo Ednilson de (Org.). Duas décadas de políticas afirmativas na UFMG: debates, implementação e acompanhamento. Coleção Estudos Afirmativos, Rio de Janeiro, UERJ, LPP, v. 9, p. 125-142, 2018.

JESUS, Rodrigo Ednilson de. Quem quer (pode) ser negro no Brasil? Auto-declaração e Heteroidentificação racial no contexto das Cotas. Alma preta, Brasília, 15 jun. 2019. Disponível em: https://www.almapreta.com/editorias/realidade/quem-quer-pode-ser-negrobrasil. Acesso em: 19 jun. 2019. 
JORNAL A TARDE. Segunda fraude contra sistema de cotas. Jornal da Tarde. 6 fev. 2006. Disponível em: http://atarde.uol.com.br/bahia/salvador/noticias/1282435-segunda-fraudecontra-sistema-de-cotas. Acesso em: 21 ago. 2014.

KEHL, Maria Rita. Politicamente correto. Entrevista com Jurandir Freire Costa. Teoria e Debate, n. 18, Fundação Perseu Abramo, São Paulo, mai./jun/.jul. 1992. Disponível em: https://teoriaedebate.org.br/1992/06/02/politicamente-correto/. Acesso em: 20 nov. 2017.

LIMA, Danilo Rosa de. Fraude nas Cotas: a culpa é de quem? Alma preta, Brasília, set. 2015. Disponível em: https://www.almapreta.com/editorias/o-quilombo/fraude-nas-cotas-a-culpa-ede-quem. Acesso em: 29 dez. 2018.

MADRUGA, Sidney. Discriminação Positiva: ações afirmativas na realidade brasileira. Brasília: Brasília Jurídica, 2005.

MAGNONI, Maria Salete. Lei de Cotas e a mídia brasileira: o que diria Lima Barreto? Estudos Avançados, Instituto de Estudos Avançados da Universidade de São Paulo, São Paulo, v. 30, n. 87, p. 299-312, 2016.

MUNANGA, Kabengele. Rediscutindo a mestiçagem no Brasil: identidade nacional versus identidade negra. Belo Horizonte: Autêntica, 2004.

NASCIMENTO, Alessandra Santos; FONSECA, Dagoberto José. Classificações e identidades: Mudanças e continuidades nas definições de cor ou raça. In: PETRUCCELLI, José Luis; SABOIA, Ana Lúcia. Características étnico-raciais da população: classificações e identidades. Brasília, IBGE, Rio de Janeiro, 2013. p. 51-82. Disponível em: https://biblioteca.ibge.gov.br/visualizacao/livros/liv63405.pdf. Acesso em: 7 ago. 2017.

NEVES, Clarissa Baeta. Trajetórias escolares, famílias e políticas de inclusão social no ensino superior. In: ROMANELLI, Geraldo; NOGUEIRA, Maria Alice; ZAGO, Nadir. Família \& Escola: novas perspectivas de análise. Petrópolis, Vozes, 2013, p. 278-311.

NOGUEIRA, Oracy. Preconceito racial de marca e preconceito racial de origem. Sugestão de um quadro de referência para a interpretação do material sobre relações raciais no Brasil. São Paulo, Tempo Social, revista de sociologia da USP, v. 19, n. 1, p. 287-308, nov. 2007.

NUNES, Gérson de Oliveira. Informe publicitário cigarro Vila Rica, O que era a lei de Gérson? Ele mesmo explica. Entrevista à Rádio Tupi, Youtube, Vila Rica. 1976. Disponível em: https:/www.youtube.com/watch?v=FMGGEQuGw4. Acesso em: 10 dez. 2017.

OLIVEIRA, Junia; RICCI, Larissa. Escândalo das cotas na UFMG leva processo a 34 estudantes e coloca outros 28 sob suspeita. Estado de Minas, Belo Horizonte, 18 maio 2018. Disponível em:

https://www.em.com.br/app/noticia/gerais/2018/05/18/interna_gerais,959667/escandalo-decotas-na-ufmg-34-processados-28-e-suspeitos-por-fraude.shtml. Acesso em: 11 dez. 2018.

OSÓRIO, Rafael Guerreiro. A classificação de cor ou raça do IBGE revisitada. In: PETRUCCELLI, José Luis; SABOIA, Ana Lúcia. (Org.). Características étnico-raciais: classificações e identidades. Rio de Janeiro: IBGE, 2013. p. 82-98.

PETRUCCELLI, José Luis. A cor denominada: estudos sobre a classificação étnico-racial. Rio de Janeiro: DP\&A, 2007.

PORTAL 7 SEGUNDOS. MPF solicita esclarecimentos da Ufal com relação a supostas fraudes em cotas. Maceio, 15 ago. 2016. Disponível em:

https://arapiraca.7segundos.com.br/noticias/2016/07/15/69572/MPF/solicita-esclarecimentosda-ufal-com-relacao-a-supostas-fraudes-em-cotas.html. Acesso em: 09 dez. 2018.

PORTAL G1 SUL DE MINAS. Universidade Federal de Lavras investiga alunos por uso indevido de cotas étnico-raciais. Jornal da EPTV, 1a edição, Lavras, MG, 18 nov. 2017. 
Disponível em: https://g1.globo.com/mg/sul-de-minas/noticia/universidade-federal-de-lavrasinvestiga-alunos-por-uso-indevido-de-cotas-etnico-raciais.ghtml. Acesso em: 12 dez. 2018.

PORTAL G1 ZONA DA MATA. Estudantes da UFJF investigados por fraude em cotas começam a depor nesta sexta, Juiz de Fora, G1, 09 ago. 2018. Disponível em https://g1.globo.com/mg/zona-da-mata/noticia/2018/08/09/estudantes-da-ufjf-investigadospor-fraude-em-cotas-comecam-a-depor-nesta-sexta.ghtml. Acesso em: 12 dez. 2018.

ROMMEL, Celso. Bahia: Aluno denuncia fraude em cotas de Medicina e é processado por pró-reitor. Ipiaú Online, 27 set. 2018. Disponível em: https://ipiauonline.com.br/bahia-alunodenuncia-fraude-em-cotas-de-medicina-e-e-processado-por-pro-reitor/. Acesso em: $13 \mathrm{dez}$. 2018 .

ROSEMBERG, Fúlvia. O branco no IBGE continua branco na ação afirmativa? Estudos Avançados, São Paulo, v. 18, n. 50, p. 61-65, 2004. Disponível em: https://www.scielo.br/pdf/ea/v18n50/a07v1850.pdf. Acesso em: 23 dez. 2007.

SANTOS, Adilson Pereira dos. Gestão universitária e a Lei de Cotas. Curitiba: Appris, 2020.

SANTOS, Adilson Pereira dos. Implementação da lei de cotas em três universidades federais mineiras. 2018. 220f. Tese (Doutorado em Educação)- Programa de Pós-Graduação em Conhecimento e Inclusão Social em Educação, Faculdade de Educação, Universidade Federal de Minas Gerais, Belo Horizonte, 2018. Disponível em https://repositorio.ufmg.br/handle/1843/BUOS-AWKLUJ. Acesso em: 2 jan. 2020.

SANTOS, Adilson Pereira dos. Itinerário das ações afirmativas no ensino superior público brasileiro: dos ecos de Durban à Lei das Cotas. Revista de Ciências Humanas UFV, Viçosa/MG, v. 12, n. 2, p. 289-317, jul./dez. 2012. Disponível em https://periodicos.ufv.br/RCH/article/view/3445. Acesso em: 12 set. 2019.

SANTOS, Adilson Pereira dos; CAMILLOTO, Bruno; DIAS, Hermelinda Gomes. A heteroidentificação na UFOP: O controle social impulsionando o aperfeiçoamento da política pública. Revista da $A B P N$, v. 11, p. 15-40, n. 29 jun.-ago. 2019.

SANTOS, Hélio; SOUZA, Marcilene Garcia de; SASAKI, Karen. O subproduto social advindo das cotas raciais na educação superior do Brasil. Revista Brasileira de Estudos Pedagógicos. INEP. Brasília, v. 94, n. 237, p. 542-563, 2013.

SANTS, Mirtes. As fraudes nas cotas raciais e a fiscalização das autodeclarações nos concursos públicos e nas universidades. Coletivo Negrada. Organização de Estudantes, Negr@s, Indígenas e Cotistas - UFES. Vitória/ES, 05 ago. 2016. Disponível em: https://coletivonegrada.wordpress.com/2016/08/05/as-fraudes-nas-cotas-raciais-ea\%20fiscalizacao-das-autodeclaracoes-nos-concursos-publicos-e-nas-universidades/. Acesso em: 11 dez. 2018.

SPERB, Paula. Fraude nas cotas: 'São brancos ocupando vagas indevidamente'. Veja. Porto Alegre, 5dez2017. Disponível em: https://veja.abril.com.br/blog/rio-grande-do-sul/fraude-nascotas-sao-brancos-ocupando-vagas-indevidamente/. Acesso em: 12 dez. 2018.

SUL 21. UFSM indefere matrículas de estudantes. Santa Maria, Sul 21, 03 fev. 2016. Disponível em: https://www.sul21.com.br/ultimas-noticias/geral/2016/02/ufsm-cancelamatricula-de-cotista-que-nao-tem-aparencia-de-pardo/. Acesso em: 13 dez. 2018.

TELLES, Edward. Racismo à brasileira: uma nova perspectiva sociológica. Rio de Janeiro: Relume-Dumará: Fundação Ford, 2003.

TOLEDO, Luiz Fernando Antunes. 1/3 das universidades federais tem denúncia em cota racial; governo quer avaliação visual. O Estado de São Paulo. São Paulo, 12 jan. 2018. Disponível em: https://educacao.estadao.com.br/noticias/geral,13-das-federais-tem-denunciaem-cota-racial-governo-quer-avaliacao-visual,70002147782. Acesso em: 02 dez. 2018. 
TOLEDO, Luiz Fernando Antunes. Consulta Sistema Eletrônico do Serviço de Informação ao Cidadão, 2016.

UFAL. Universidade Federal de Alagoas. Pró-Reitoria de Graduação. Edital $n^{\circ}$ 03/2019, de 21 de janeiro de 2019. Dispõe sobre processo seletivo para ingresso nos cursos de graduação presenciais da UFAL 2019.1 - SISU/MEC-2019.1. Disponível em:

$\mathrm{http}: / /$ www.copeve.ufal.br/index.php?opcao $=$ concurso\&idConcurso=388. Acesso em: 12 mar. 2020.

UFGD. Universidade Federal de Grandes Dourados. UFGD esclarece. Dourados, 3 set. 2019. Disponível em: https://www.ufgd.edu.br/noticias/ufgd-esclarece. Acesso em: 12 out. 2019.

UFJF. Universidade Federal de Juiz de Fora. Comissão conclui apuração de 92 denúncias de fraude nas cotas. Juiz de Fora, 16 jul. 2018. Disponível em:

https://www2.ufjf.br/noticias/2018/07/16/comissao-conclui-apuracao-de-92-denuncias-defraude-nas-cotas/. Acesso em: 10 dez. 2018.

UFLA. Universidade Federal de Lavras. Termo de Adesão ao Sistema de Seleção Unificada, edição 2019/1. Lavras, 15 nov. 2017. Disponível em:

http://www.dips.ufla.br/copese/upload/File/2019_1/SISU/DIVULGACAO/Termo\%20Ades\% C3\%A3o\%202018-1.pdf. Acesso em: 13 dez. 2018.

UFPE. Universidade Federal de Pernambuco. Edital Processo Seletivo SiSU (2019).

Recife/PE, 28 dez. 2018. Disponível em: https://www.ufpe.br/formas-de-ingresso/sisu-ufpe. Acesso em: 30 dez. 2018.

UFSCAR. Universidade Federal de São Carlos. UFSCar debate prevenção de fraudes nas ações afirmativas. São Carlos/SP. Rádio UFSCar, 29 nov. 2017. Disponível em: https://www.radio.ufscar.br/noticias-ufscar/ufscar-debate-prevencao-de-fraudes-nas-acoesafirmativas/. Acesso em: 14 dez. 2018.

UNIFESP. Universidade Federal de São Paulo. Memo. $N^{o}$ 465/2016 ProGrad. São Paulo, 9 de agosto de 2016. Sistema Eletrônico do Serviço de Informação ao Cidadão Acesso, Pedido: 23480013797201621 , de 31 de julho de 2016.

VENÂNCIO, Pedro. O crime que compensa: o "gato" no futebol brasileiro. Lex Sports. Leis e regras desportivas. Noticiários nacionais e internacionais, 2017. Disponível em:

http://lexsports.com.br. Acesso em: 18 jan. 2018. 